\title{
LEARNING ACTIVITIES IN HIGHER ORDER THINKING SKILL (HOTS) ORIENTED LEARNING CONTEXT
}

\author{
Nofrion $^{1}$, Bayu Wijayanto ${ }^{2}$ \\ ${ }^{1,2}$ Lecturer of Department of Geography Education, Faculty of Social Sciences \\ Padang State University, Indonesia \\ Email: dion_geografi@yahoo.com
}

Received: 17 July 2018/Revised: 1 August 2018/Accepted: 18 August 2018/Published online: 28 August 2018

\begin{abstract}
The development of 21st century life requires the higher-level thinking ability developmental for learners. HOTS learning is characterized by; 1) Analysis, Evaluation and Creating, 2) Logical reasoning, 3) Consideration and critical thinking, 4) Problem Solving and Creative Thinking. One effort that can be done by educators to develop higher-level thinking ability for learners is by facilitating learners to do Advanced Learning Activities (ABL) that include: 1) processing/ analyzing, 2) Communicating/ dialogue, 3) discuss/ collaborate, 4) presents/ constructs. ABL is a continuation of Basic Learning Activities which includes; 1) Observing (combination of seeing and hearing), 2) trying/ questioning, 3) searching/ collecting. Therefore, in learning, educators should be more focused on giving learners space to do ABL while still allowing time for ABD as a warm-up activity or initial activity (Schaffolding). The way that can be done as a trigger of Advanced Learning Activities is to present more questions/ tasks/ problems on high cognitive level that is C4, C5, and C6 in every learning. High-level questions/ tasks/ problems will also encourage learners to dialogue and discuss so that collaboration in learning will be created.
\end{abstract}

Keywords: Basic Learning Activity/ABD, Advanced Learning Activities/ ABL, HOTS oriented Learning

\section{Introduction}

In a global context, UNESCO states the four pillars of education consisting of learning to know, learning to do, learning to be and live together in peace. In some studies, especially in Indonesia, it is added with the fifth pillar of learning to believe in God. This addition is based on the fact that the Indonesian nation is a religious nation and it is contained in the UU No. 20 of 2003 onNational Education System stating that one of the goals of national education is to develop the potential of learners in order to become a man of faith and cautious to the one almighty God.

In 2009, a report entitled "Learning for the 21st Century" published "Framework for 21st Century Learning" which describes four competencies or areas to be mastered by learners, covering "1) core subject and 21st century themes, 2) learning and innovative skills, 
3) information, media and technology skills and 4) life and career skills "(Marzano\&Heflebower, 2012. The four competencies must be possessed by graduates of educational institutions in order to compete in the global association.

Therefore, in the 21 st century schools and other educational institutions should be able to develop 21st Century Competencies/ Skills. In Indonesia, this has been adopted by the Curriculum 2013 with the term "4K" which in Indonesian is (a) Kecakapan berfikir kritisdan pemecahan masalah (Critical Thinking), (b) Kecakapan berkomunikasi (Communication Skills), (c) Kreativitas dan Inovasi (Creativity and Innovation), (d) Kolaborasi (Collaboration).

The four 21st Century Skills can be realized if supported by learning that is oriented to the development of Higher Order Thinking Skill (HOTS) and optimize the three main energies in learning that are energy of educator, energy of students and energy of learning environment (Prayitno, 2009: 200-222). The combination and collaboration of these three energies will be reflected in the interaction between learners and educators, learners with other learners as well as interactions with various learning resources in a learning environment. This condition is expected to occur within the classroom as stated in UU No. 20 of 2003 on National Education System, article 1 paragraph 20.

However, in the current practice of learning is still found a lot of conventional learning that is teacher-centered, high competition, minimal interaction and learning activities and collaboration has not been created. If this condition is maintained then it is difficult to create students who have higher-level thinking ability characterized by the creativity in learning, critical and analytical thinking skills, communicative and collaborative. Based on this, in this article the author tries to suggest ideas about the need to redefine the activities in learning. This is very necessary because with a deeper understanding of the type and level of learning activities will guide educators to design learning. The author calls itwith Advanced LearningActivity or ABL. The authors also emphasize the importance of understanding the difference between Basic Learning Activity (ABD) with Advanced Learning Activities (ABL). Basic Learning Activities are the initial activities and the steps (schaffolding) for Advanced Learning Activities. In order to design HOTS oriented Lesson, the educator must provide more portions to the Advanced Learning Activities in the lesson. 


\section{Review of Related Literature}

\subsection{HOTS learning}

HOTS learning is a learning that develops higher-order thinking ability of learners, more than just the ability to memorize/ recall, restate, remember and refer without scientific reasons (recite). Questions and tasks and problems in learning are useful for:
a. Transfer one concept to another
b. Process and apply information
c. Looking for links from different sources
d. Use information to resolve the problems
e. Review ideas and information critically.

Brookhart (2010: 14) in his book "How to Assess Higher Order Thinking Skills in Your Classroom" states that there are five categories of higher-level thinking skills/ HOTS namely:

a. Analysis, Evaluation and Creating. All of these are the top level in the realm of cognitive/ knowledge in the Bloom Revision's version (2001).

b. Logical reasoning

c. Consideration and critical thinking

d. Problem Solving and Creative Thinking.

To get a more operational explanation of HOTS, Anderson and Krathwohl (2001) have revised Bloom's Taxonomy by modifying the cognitive level of learners as shown in the following table:

Table 1. Dimension of Thinking Process

\begin{tabular}{|c|c|c|c|c|c|}
\hline No & $\begin{array}{c}\text { Cognitive } \\
\text { Level }\end{array}$ & Dimension & Infromation & KKO & Category \\
\hline 1 & $\mathrm{C} 1$ & Knowing & Recalling & Remember, register, repeat, mimic & LOTS \\
\hline 2 & $\mathrm{C} 2$ & Understanding & Explain ideas / concepts & Explain, classify, receive, report & MOTS \\
\hline 3 & $\mathrm{C} 3$ & Apply & $\begin{array}{l}\text { Use information on } \\
\text { different domains }\end{array}$ & Uses, demonstrates, operates & \\
\hline 4 & $\mathrm{C} 4$ & Analyze & $\begin{array}{l}\text { Specifies the elements/ } \\
\text { aspects }\end{array}$ & $\begin{array}{l}\text { Comparing, } \\
\text { Checking, criticizing, testing }\end{array}$ & HOTS \\
\hline 5 & C5 & Evaluate & Make the final decision & $\begin{array}{l}\text { Evaluate, assess, disprove, decide and } \\
\text { vote and support }\end{array}$ & \\
\hline 6 & C6 & Creating & $\begin{array}{l}\text { Creating your own } \\
\text { ideas }\end{array}$ & Construct, develop & \\
\hline
\end{tabular}


Source: Ministry of Education and Cultural of Indonesia (2017)

Further explanation of cognitive level grouping includes:

a. Knowledge and understanding (Level 1), includes C1 and C2.

b. Application (Level 2), includes C3.

c. Reasoning (Level 3), includes C4, C5 and C6

\subsection{Geography Learning}

Geography Learning is part of Geography. In another term known as 'geography as a science, geography as education or learning and geography as an attitude'. In Geography for Life: National Geography Standards, 2nd Edition (2012) explained that the goal of geography learning is "to equip students with the knowledge, skills, and perspectives to 'do' geography"

"(https://www.nationalgeographic.org/education/national/geographystandards/?ar $a=1$ accessed on July $20^{\text {th }}$, 2017.) That means the purpose of learning Geography is to equip students with knowledge, skills and geographical perspective. Based on these objectives, the three main pillars of learning geography are:

a. Geography content/ theme/ essential that is related to the material or what is learned.

b. Geography skills that include;

1) Posing geography question or a student's skill in identifying problem and asking geographical question.

2) Acquiring geographic information or the ability to collect data including observations and measurements of geographical phenomena.

3) Organizing geographic information or the ability to organize or process data

4) Analyzing geographic information or the ability to analyze data to answer questions or solve problems

5) Answering and designing solution or ability to answer or solve problems and

6) Communicating geographic information that is the ability to communicate or inform geography data to the audiences like a teacher in learning process.

c. Geography perspectives

Perspective is a way of looking at something. In geography education there are two geographical views namely spatial perspective and ecological perspective. In Indonesia, it is 
commonly added with one more type of perspective, which is a complex region perspective. In the context of the curriculum is known as Geographic approaches (Parjito, 2015: 248-249).

\subsection{Learning Activity}

The way to know someone learns or not is through the learning activity that is shown during the lesson. This method is easier and faster to observe so that the teacher can observe it throughout the lesson. Even more, so many research has proven that learning activity is very influential on learning outcomes.

Learning activities are all activities that students do in the learning process, starting from physical to psychic activity (Hamalik, 2001: 171). In his more recent book, Hamalik (2010: 28) states that learning activities are all activities undertaken in the process of interaction (teachers and students) in order to achieve learning objectives. More concisely, Sardiman (2010: 100) explains that learning is both physical and mental activities that are interrelated. From the three formulationsof learning activities above, it can be abstracted that learning activities are activities that students do during learning both physical and mental that support the achievement of learning and learning objectives.

Furthermore, Paul D. Diedrich in Hanafiah\&Suhana (2010: 24) considers that learning activities can be divided into eight groups, namely: (a) Visual activities ie. reading, viewing pictures, observing experiments, demonstrations, exhibitions and observing others working or playing; (b) Oral activities, for examplebrings up a fact or principle, relate an event, asking a question, give advice, express opinions, interview, discuss and interruptions; (c) Listening activities, for example listening to material presentations, listening to conversations or group discussions, or listening to the radio; (d) Writing activities, for example writing stories, writing reports, checking essays, copying materials, making outlines or summaries, and doing tests and filing questionnaires; (e) Drawing activities, for example drawing, creating graphs, charts, maps and patterns; (f) Motor activities, for example experimenting, selecting tools, conducting exhibitions, modeling, organizing games, and dancing and gardening; (g) Mental activities, for example contemplating, recall, solving problems, analyzing factors, looking at relationships, and making decisions; (h) Emotional activities, for example interest, differentiate, courageous, calm, bored and nervous. 


\subsection{Ideas on Basic Learning Activities/ ABD and Advanced Learning Activities/ ABL}

\section{a. Basic Learning Activities/ ABD}

Basic learning activities here mean a learning activity related to sensory sensation against the existing objects and activities that do not require higher-thinking process, like the activity of seeing, listening, asking, trying, searching, collecting and its kind. To simplify, all these activities are divided into three basic learning activities, namely; 1) Observing (combination of seeing and hearing), 2) trying/ questioning, 3) searching/ collecting. Observing learning activities is a combination of viewing and listening activities.

For example, when the teacher presents a lesson, showing a video or displaying a picture, the student who gives attention with the indicator of his eyes are fixed on the object and his ears are hearing, so that the student has done the observing learning activity. The trying/ questioning learning activity is when the student tries to ask questions, trying to take opportunity that the teacher gives such as posses or pasting things or trying to answer the light questions the teacher gives at the beginning of the lesson. Also included in the trying/ questioninglearning activity is when the student comes to the front of the class to give an opinion or response to something that the teacher presents with the note that it has not touched the main lesson substance. The third basic learning activity is searching/ collecting. Included in this category is learning activities such as looking for something that the teacher requested and collecting information. For example, a teacher asks students to locate a city on a map or ask students to collect data about the number of objects exist in an image and so on. These are basic and intermediate learning activities (LOTS and MOTS). The author's opinion is relevant to Silbermen (2006: 10) who writes that to learn something well, we need to start with (basic learning activities) such as listening, seeing and asking questions.

\section{b. Advanced Learning Activities/ ABL}

Advanced Learning Activity/ ABL is a learning activity that demands the middle and higher thinking process. Included in the advanced learning activities are processing, analyzing, communicating, dialogue, discussing, collaborating, presenting, and constructing. To be more simply, Advanced Learning Activity/ ABL formulated into; 1) process/ analyze, 2) communicate/ dialogue, 3) discuss/ collaborate, 4) present/ construct. Student involvement 
in learning by doing advanced learning activities is expected can develop middle and high thinking skills (MOTS and HOTS).

In accordance with current curriculum style (Curriculum 2013), teacher should be more focus on designing learningactivities that encourages students to do Advanced Learning Activities/ ABL. Choosing the lecturing as the main method of learning will only give sensation to the two main senses of the student that is sight and hearing. Even if there is a lecture that triggers the brain to think, mostly only limited to the basic level because with the lecturing method, the delivery of the material is very solid while the human brain's ability to digest the word and the sentence at a time has its limits and is strongly influenced by "noise" as well as the classroom atmosphere. Silbermen (2006: 9) states that we can just tell something to students quickly. However, students will forget what we are telling faster. That is, the lecture method as the main method in learning has the potential to make children quickly forget the material presented by the teacher because of the limitations of sensation felt by the child so that the process of perception and memory formation is less optimal. Therefore, teachers need to find ways and strategies to encourage advanced learning activities among students as learning takes place.

One way that can be done is to provide questions/ tasks/ exercises that challenge students. Silbermen (2006: 9) suggests that one indicator of learning activities that running effectively and efficiently is the availability of many tasks that challenge students using the brain to think hard. A figure of cognitive learning theory, Piaget in Woolfolk (2009: 79) states that education should be "form not furnish" which means, education is to form or develop the mind rather than fill it with various information. By presenting challenging questions/ tasks/ exercises, students have room to develop.

Therefore, teachers must prepare high-level questions/ tasks/ problems to be undertaken by learners in learning. The questions/ task/ problem must be at level 3 that is $\mathrm{C} 4 /$ analyze, $\mathrm{C} 5 /$ evaluate and $\mathrm{C} 6 /$ create. 
Table 2. Example of HOTS, MOTS and LOTS questions in Geography Subjects

\begin{tabular}{|c|c|c|c|}
\hline No & $\begin{array}{c}\text { Cognitive } \\
\text { Level }\end{array}$ & Cognitive Level & Sample of Questions \\
\hline 1 & $\mathrm{C} 1$ & Level 1: & Salah satu tipe bencana menurut UU No.24 Tahun 2007 tentang \\
\hline 2 & $\mathrm{C} 2$ & $\begin{array}{l}\text { Measuring knowledge of } \\
\text { facts, concepts and } \\
\text { procedures }\end{array}$ & $\begin{array}{l}\text { Penanggulangan Bencana adalah : } \\
\text { a. Geologis } \\
\text { b. Hidrometeorologis } \\
\text { c. Alam } \\
\text { d. Konflik } \\
\text { e. Kegagalanteknologi }\end{array}$ \\
\hline \multirow[t]{3}{*}{3} & $\mathrm{C} 3$ & $\begin{array}{l}\text { Level } 2 \\
\text { Includes the dimensions of } \\
\text { the process of thinking and } \\
\text { applying }\end{array}$ & $\begin{array}{l}\text { Wabah malaria banyakterjadi di daerah pegunungan, pada awal } \\
\text { dan akhir musim hujan, karena: } \\
\text { a. Kondisi berhutan lebat } \\
\text { b. Banyak genangan air jernih } \\
\text { c. Kurangnya usaha pemberantasan } \\
\text { d. Budaya hidup masyarakat } \\
\text { e. Kondisi iklim sesuai }\end{array}$ \\
\hline & & & Or, \\
\hline & & & $\begin{array}{l}\text { Daerah A pada tahun } 2010 \text { memiliki tingkat pertumbuhan } \\
\text { penduduk sebesar } 1,5 \% \text { per tahun. Berdasarkan data tersebut, } \\
\text { Daerah A diperkirakan jumlah penduduknya akan menjadi dua } \\
\text { kalinya pada tahun: } \\
\text { a. } 2047 \\
\text { b. } 2057 \\
\text { c. } 2067 \\
\text { d. } 2070 \\
\text { e. } 2077\end{array}$ \\
\hline 4 & $\mathrm{C} 4$ & Level 3: & Angin tenggara setelah melintasi khatulistiwa akan mengalami.. \\
\hline 5 & C5 & Have high logic and & a. Pembelokan ke arah timur laut \\
\hline 6 & C6 & $\begin{array}{l}\text { reasoning to solve the } \\
\text { problems based on levels } 1 \\
\text { and } 2\end{array}$ & $\begin{array}{l}\text { b. Menuju barat laut } \\
\text { c. Dibelokkan oleh Gaya Coriolis ke arah barat } \\
\text { d. Berbalik ke arah barat daya } \\
\text { e. Semua salah }\end{array}$ \\
\hline
\end{tabular}

Source: Nofrion (2017)

High-level questions will not only encourage students to think hard but will also motivate them to dialogue and discuss so that collaboration occurs (Nofrion et al, 2018: 5-8).

After the students are given the questions, then the teacher has the task to observe student learning activities. Good observation will be the basis for improvements of the next learning.

\section{Conclusion}

Advanced Learning Activity/ ABL is a learning activity that is expected to provide opportunities for students to develop higher-order thinking skills/ HOTS. One effort that can be done by educators to trigger the occurrence of Advanced Learning Activity/ ABL is to give the questions/ task/ problem that is at level 3 or at the level of C4, C5 and C6. High-level 
questions will not only encourage students to think hard but will also motivate them to dialogue and discuss so that collaboration occurs.

\section{References}

Brookhart, L. Susan. 2010. How to assess Higher Order Thinking Skills in Your Class. ASCD. Alexandria, Virginia USA

Hamalik, Oemar. 2001. Learning strategies. Jakarta. BumiAksara 2010. Learning strategies. Jakarta. BumiAksara

Hanafiah, Nanang \& Suhana, Cucu. 2010. Learning Strategies. Bandung. Refika Aditama

Marzano, R. J., \& Kendall, J. S. (2007) .The new taxonomy of educational objectives (2nd ed.). Thousand Oaks, CA: Sage

Marzano, R. J \& Heflebower, T. 2012.Teaching \& Assssing 21st Century Skills (The Classroom Strategies Series). EBook from marzanoresearch.com

Nofrion. 2017. Geography Learning Models and Strategies (Designing HOTS and Learning Collaborative Learning). Padang. Sukabina Publisher

N, Nofrionet al.2018. Effectiveness of EXO OLO TASK Learning Model Based on Lesson Study in Geography Learning IOP Conf. Ser .: Earth Environ. Sci. 145012038

Parjito. 2015. Vision of 21st Century Geography Education. Proceedings of the P3GI National Seminar. Poor. ISBN: 978 - 602 - 71506 - 3 - 8

Prayitno.2009 Basic Teaching and Praxis Education. Grasindo. Jakarta

Sardiman. 2010. Interaction and Motivation of Learning Teaching. Jakarta. Rajawali Press

Silbermen, L. Melvin. 2006. Active Learning: 101 Learning Methods Active Students. Bandung. Nusamedia

Law Number 20 of 2003 concerning National Education Systems

Woolfolk. 2009. Educational Psychology (Active Learning Edition), Tenth Edition. Yogyakarta. Student Library 